\title{
TRIP11/PDGFRB Fusion Gene
}

National Cancer Institute

\section{Source}

National Cancer Institute. TRIP11/PD GFRB Fusion Gene. NCI Thesaurus. Code C99686.

A fusion gene that results from a chromosomal translocation $t(5 ; 14)(q 33 ; q 32)$ which fuses the 5' part of the TRIP11 gene with the 3' part of the PDGFRB gene. This gene fusion is associated with chronic myelomonocytic leukemia. 